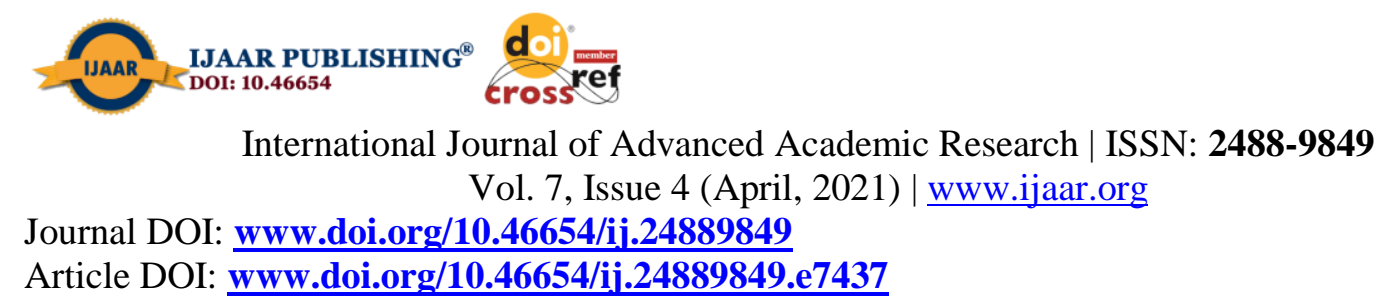

International Journal of Advanced Academic Research | ISSN: 2488-9849

Vol. 7, Issue 4 (April, 2021) | www.ijaar.org

Journal DOI: www.doi.org/10.46654/ij.24889849

Article DOI: www.doi.org/10.46654/ij.24889849.e7437

\title{
HYDROGEOPHYSICAL AND AQUIFER PROTECTIVE CAPACITY OF ABAKALIKI/AFIKPO AREA AND ENVIRONS, SOUTHEASTERN NIGERIA USING GEO- SOUNDING DATA
}

\author{
*10si-Okeke, I.; ${ }^{1}$ Opara, A. I.; ${ }^{1}$ Oli, I.C.; ${ }^{1}$ Udeh, H.M. and ${ }^{1}$ Abiahu, C.M. \\ ${ }^{1}$ Department of Geology Federal University of Technology Owerri, Nigeria, Africa \\ *Corresponding author: Email: ifeanyi.osi.okeke@gmail.com, Phone no: 08034476993
}

\begin{abstract}
This work was carried out to evaluate the hydrogeological and geophysical properties of Abakaliki and Afikpo environs. Forty-seven (47) Vertical Electrical Sounding data were acquired with electrode spacing $(A B / 2)$ of $500 m$ using Schlumberger electrode configuration. Conventional curve matching techniques were used to interpret the data and obtain initial model parameters. Results of the study showed 3-7 electric layers which indicate multiple aquifer system. QQH, QHK, KHK and QQHK models were the Vertical Sounding curves obtained. The aquiferous layers make up the third and fourth layers. The resistivity of the aquifer varies from $10.74 \Omega \mathrm{m}$ to $13201 \Omega \mathrm{m}$ with an average of $1013.58 \mathrm{\Omega m}$. Aquifer depth ranges from $6.2 \mathrm{~m}$ to $92.5 \mathrm{~m}$ with an average aquifer depth of $27.07 \mathrm{~m}$, while the aquifer thickness varies from $2.3 \mathrm{~m}$ to $55.87 \mathrm{~m}$ with an average of $15.61 \mathrm{~m}$. Transverse resistance varies from $65.34 \Omega \mathrm{m}^{2}$ to $7079.14 \mathrm{\Omega m}^{2}$ with an average of $9966.29 \mathrm{\Omega m}^{2}$; and the longitudinal conductance varies from $0.00018 \Omega^{-1}$ to $1.65 \Omega^{-1}$ with an average of $0.026 \Omega^{-1}$. From the study, $49 \%$ of the study area falls under the poor protective rating while $21 \%$ falls under the weak rating with $25 \%$ and $5 \%$ which makes up the moderate and good ratings respectively. Using the average longitudinal conductance, it is observed that the study area is moderately protected.
\end{abstract}

Key words: Resistivity; Vertical Electrical Sounding: Longitudinal conductance; Transverse resistance; Vulnerability. 


\section{Introduction}

Access to fresh and potable water for domestic and industrial use is a major challenge in Abakaliki/Afikpo areas due to the collapse of the public water supply schemes. Most public water schemes that provide pipe-borne water in the area have been abandoned by the government whose duty, it is to provide this all important resource. Most households do not have access to pipe borne water consistently. With population explosion in towns like Abakaliki, Afikpo, Izzi and Ishiagu occasioned by the presence of several mining and quarrying companies such as Crushed Rock Industries Limited, Setraco Nigeria Limited etc., a greater need for potable water has become obvious. More so, the need to assess the protective capacity of the aquifer in the area cannot be overemphasized as there is the danger of its contamination from surface industrial effluents and pollutants emanating from mining and quarrying activities in the area. An alternative means water includes surface water, hand dug wells and boreholes. Surface water is usually associated with diseases like typhoid, cholera etc. it has been estimated that roughly five to ten million people die annually to water related diseases and most of them are little children (Snyder and Merson, 1982). This means that groundwater is the safest and best source of potable water for Ebonyi state inhabitants. On the other hand, the availability and use of the groundwater is also becoming troublesome. Although some of the drilled boreholes yield water at economic quantities all year round, some are productive only at the height of the rainy season, and the rest are totally unproductive, and are referred to locally as 'abortive' boreholes. The characteristics mentioned above can be related to the existence of fractures and the complete absence of weathered areas within the investigated area.

Geometric, geo-hydraulic and protective capabilities of aquifers are some of the fundamental properties defining the hydrogeology of any given area. In general, these properties are calculated using geological details, which are typically derived from drilled wells. In case of non-disponibility of well data, however, from existing boreholes within the study area, data from surficial electrical resistivity measurements may be used to predict aquifer properties. Vertical Electrical Sounding (VES) is very effective in determining the fundamental aquifer properties and protective capacities. It is well known that the electrical resistivity data of the subsurface can be used to provide important information for detailed aquifer delineation and characterization (Opara et al. 2012). Surficial electrical resistivity techniques have therefore been used extensively in delineating groundwater resources in various parts of the world (Niwas and Singhal 1981). Similarly, several scholars have previously established a strong relationship between aquifer geohydraulic properties and aquifer resistivity indicating an inverse relationship (Niwas and Singhal 1981). Researchers have applied this relationship to estimate hydraulic aquifer characteristics, geometric capacity, and susceptibility using data on electrical resistivity (Obiora et al. 2016a, b; Ugada et al. 2013).

Resistivity techniques are well established and widely used to solve a variety of engineering, geological, hydrogeological and environmental challenges because they are non-evasive and cost effective (Ward, 1990). The primary aim of the resistivity method is to quantify the possible surface variations due to the current flow within the field. The hydraulic and electrical conductivities are mutually dependent because the mechanism that controls fluid flow and electrical current and conduction is generally regulated by the same physical parameters and lithological properties. The current flow and conduction in the soil are extremely variable, therefore, the measured resistivity values are not absolute but relative. Several authors have therefore delineated shallow aquifers and estimated aquifer hydraulic 
parameters using surface geophysical methods in different parts of the world (Ugada et al., 2012, Ejiogu et al., 2019). Vertical electrical sounding (VES) investigations have been widely employed in aquifer investigations across the world, both in basement and sedimentary terrains (Zorhy et al., 1974; El - Hussaini et al., 1995; Ayers, 1989; Vchery and Hobbs, 2003; Akaolisa, 2006; Tizro et al., 2010; Arabi et al., 2010; Oni et al, 2017 and Eyankware et al., 2020).

Aquifer protective capacity is the aquifer's ability to protect itself from damage from anthropogenic surface sources. Protective capacity or vulnerability of aquifers is an essential feature necessary for the sustainable use and management of groundwater. Protecting groundwater from contamination is a function of the layers above it. However, the degree of pollution depends on certain intrinsic properties of aquifer systems that may include topography, porosity / permeability, and climate influences. The protective ability of groundwater is a feature not only of the properties of the groundwater flow system but also of its proximity to contaminant sources, the existence of the contaminant and other factors that may trigger the potential contaminants to reach the groundwater resources as quickly as possible (Michael et al. 2005). Usually, geological techniques that use parameters such as depth to water, net recharge, aquifer media, soil media, topography, impact of the vadose zone and hydraulic conductivity, etc. are used to estimate aquifer protective capacities. Such techniques which include DRASTIC, GOD, SINTACS, etc. have been used by several scholars to study issues related to aquifer protective capacity over the years (Aller et al. 1987; Navulur and Engel 1996). In very recent times, because of the paucity of data needed for the estimation of aquifer protective capacity, several empirical equations based on electrical resistivity have been used with great success to predict aquifer protective capacity (Obiora et al. 2016).

A study was carried out by Uma (1989) on the groundwater potential of the Imo River basin and shallow and deep aquifers were discovered using pump test and borehole data. Similarly, numerous researchers have previously studied parts of the study region (Imo River Basin) using parameters from Dar-Zarrouk (Ugada et al., 2013, 2014; Eke et al. 2015). Therefore, the present study is a detailed hydrogeophysical study of the area intended to delineate the shallow aquifer units in the area of study. In addition, the longitudinal conductance values produced from this analysis were used to assess the study area's aquifer protective capacity. Geophysical sounding data has also been correlated with lithological logs from boreholes and the electrical logs available for comparative purposes. It is hoped that results of this research will resolve the study area's groundwater problems. Therefore, it is important the aquifer potentials and groundwater quality be assessed as a reliable and safe source of potable water supply. This study seeks to appraise the aquifer potential in the area and asses the protective capacity of the aquifers.

\subsection{Location, Geomorphology, Drainage and Geology of the Study Area}

The study area is located within Latitude $6^{\circ} 26^{\prime} 49^{\prime \prime} \mathrm{N}$ of the equator and Longitude $8^{\circ} 01^{\prime}$ $37^{\prime}$ 'E (Figure 1) and covers 412.55 sq. km. and located in the southeast Nigeria. The area experiences an average annual rainfall ranges from over $1500 \mathrm{~mm}$ to over $2000 \mathrm{~mm}$ per annum, with temperatures rarely exceeding $38^{\circ} \mathrm{C}$. The Ebonyi formation soils are mainly hydromorphic with lesser soils in the uplands. This established land use which is mainly for the production of rice. The region is marked by undulating topography, and there is no place above sea level $400 \mathrm{~m}$. 
The Abakaliki region is underpinned by the Asu River Group (Reyment, 1965) Abakaliki Shale Formation. Sediments of the Asu River System are mainly shale, with scattered occurrences of intercalations of sandstone, siltstone with calcareous (Ofoegbu and Amajor, 1987). In the mid-Albian period, it was generally believed to have started depositing and was deposited within the lower (or southern) Benue Trough, southeastern Nigeria. Sediments in these Asu River Groups are intermediates to simple invasive, extrusive, and pyroclastic substances (Murat, 1972; Nwachukwu, 1972; Ofoegbu and Amajor, 1987; Tijani et al., 1996). The group has an average thickness of about $2000 \mathrm{~m}$ and rests on the Precambrian Basement (Benkhelil et al .1989). Abakaliki shale formation, has an average thickness of approximately $500 \mathrm{~m}$, shale is dominant, dark grey in color, blocky and non-micaceous in most areas. It is deeply folded and broken by the sequence of tectonic activities that have been taking place on the rocks (Ezeh and Anike, 2009). This has provided the shales the opportunity to house groundwater in economic quantities in some regions, while other sections still exist as aquiclude and fractures not pronounced.

The Afikpo area is underlain by Ezeaku and Nkporo Formations (Reyment, 1965, 1967) (Figure 2). Low productivity of many boreholes already drilled in the area supports the difficulty to find sustainable water supplies. The geology of the study area has been described in details by various authors (Nwankwoala, 2015; Adelana et al, 2008; Reyment, 1965) and these formations consist of thin shallow but extensive unconfined aquifer, and deep and perched aquifer (Adelana et al, 2008). The formations have variable saturated thickness and generally less than $50 \mathrm{~m}$ and $78 \mathrm{~m}$ in aquifers found in its lower and middle hydrogeological groups respectively (Reyment, 1965). 


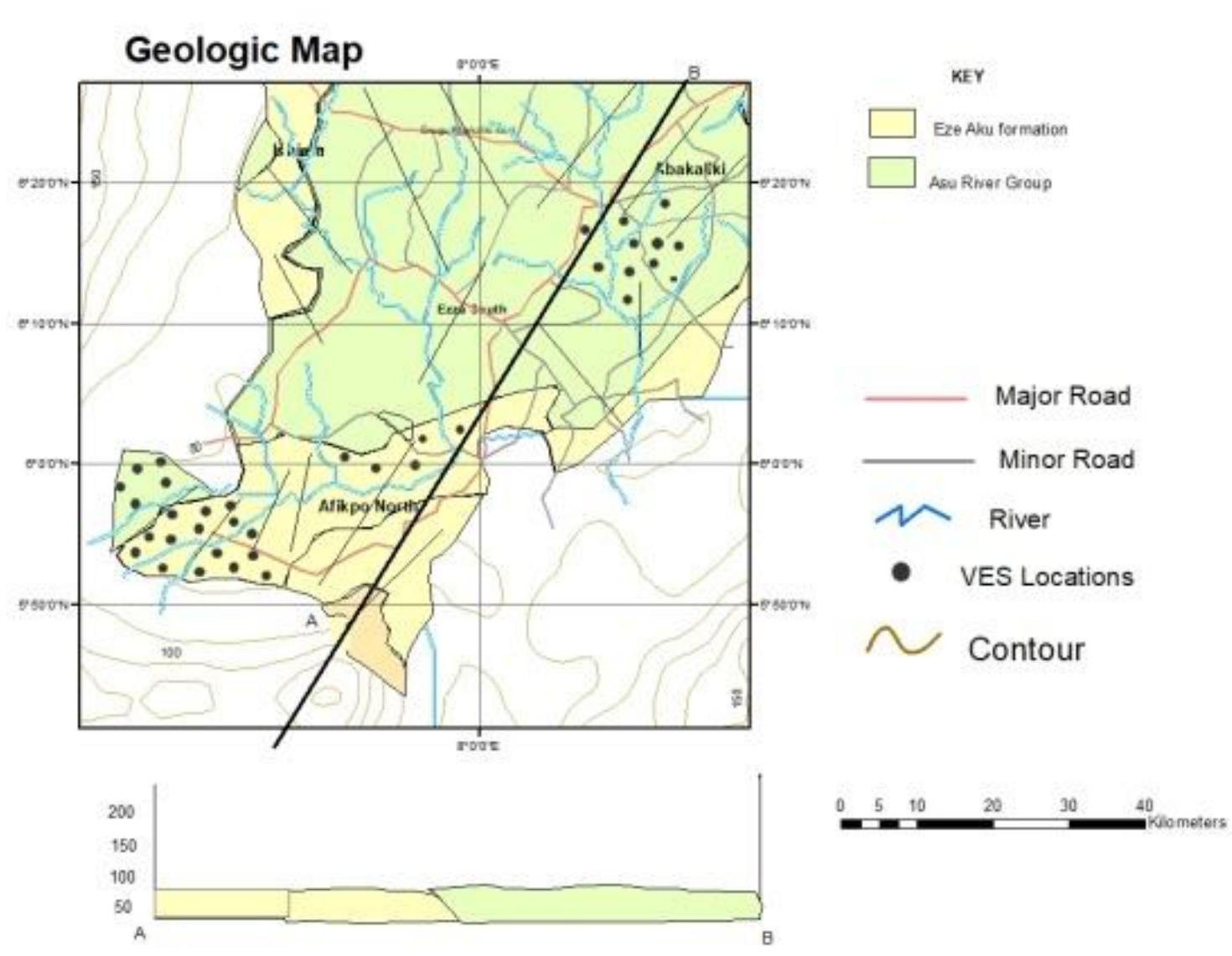

Figure 1. Geology map of the study area

\subsection{Data Acquisition and Processing}

Resistivity data was obtained using vertical electrical sounding (VES). Schlumberger electrode configuration was adopted with an electrode spacing of $150 \mathrm{~m}$. In theory, the resistivity of a material has a direct relationship with the resistance of a material.

$$
\rho_{a}=\pi\left[\frac{\left(\frac{A B}{2}\right)^{2}-\left(\frac{M N}{2}\right)^{2}}{M N}\right] \frac{\Delta V}{I}
$$

IP2WIN software aided the data processing and generated sounding curves. The data from these curves were used to determine aquifer thickness.

Dar Zarrouk parameters are parameters related to the combination of resistivity of electric layer and thickness, these are vital for understanding and analyzing geologic model (Zohdy et al. 1976). These parameters are transverse (T) and Longitudinal (S), given by: 
Journal DOI: www.doi.org/10.46654/ij.24889849

Article DOI: www.doi.org/10.46654/ij.24889849.e7437

$\mathrm{T}=\mathrm{hp}$

$\mathrm{h}$ represents the thickness of the layer in meters while $\mathrm{p}$ is the layer resistivity in ohmmeters.

\subsection{Result Presentation and Interpretation}

\subsection{Interpretation of the Layer Parameters}

The acquired field resistance data were used to produce geo-electric curves representative of the underlying geology of the study area. The arrangement of the curves for each location of the sound typically provides an understanding of the physical characteristics of the layers within that location. The curve types for the soundings gave clues to the nature of the nature of the layers between the surface and maximum depth of penetration. The curve types identified ranges from simple QQ to QH, KHK, HKK, to complex AKHH, HKHK types, reflecting different facies or lithological variations in the area. Previous work by (Ngwoke, 2016) revealed that, the occurrence of many curve forms indicates minimal uniformity of resistance patterns over the study area and the lack of uniformity of layering and alteration of layer properties due to weathering, fracturing and other geological phenomenon across study area are elements that can cause alternations in resistance patterns across the study region. The typical curve types from the study area are shown in figure 2 .

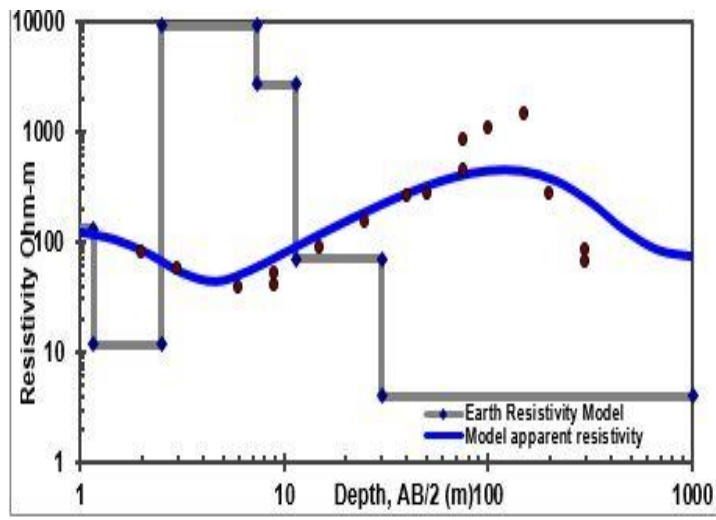

(a)

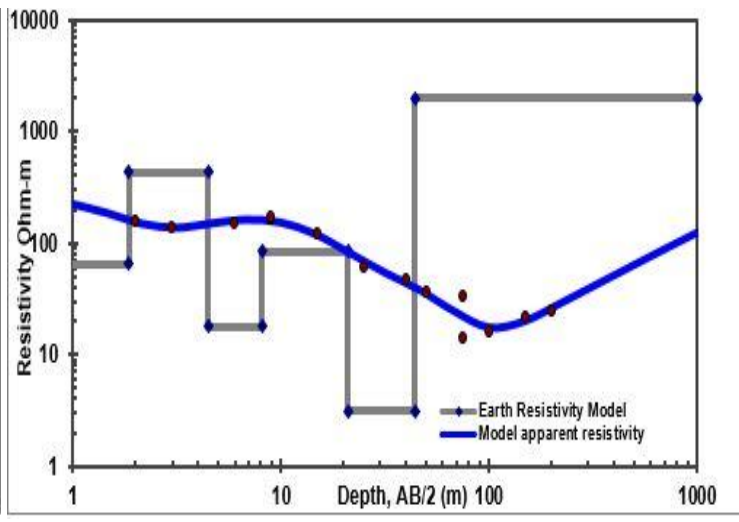

(b)

Figure 2. Sample Geo-electrical Curve Types in the study area: (a) NNPC filling Station Amasiri, Ebonyi State (b) Federal Medical Centre, Abakaliki, Ebonyi state.

Three, four, five, six and seven layers were discovered from the data after analysis. The six layer models were the most prominent occurring 19 times, followed by five layers occurring 12 times

\subsection{Aquifer Resistivity}

Aquifer resistivity across the study area was estimated from the geo-electric curves generated from the Vertical Electrical Sounding data. The aquifer resistivity varied spatially across the study area in agreement with the geological complexity of the study area as shown in (figure $3)$. 
Aquifer resistivity in Afikpo varies from as low as $24.1 \Omega \mathrm{m}$ at VES 11 to as high as 13203 $\Omega \mathrm{m}$ at VES 1 with a mean value of $4644 \Omega \mathrm{m}$. The aquiferous zones are found in the $3^{\text {rd }}$ and $4^{\text {th }}$ layers. The Abakaliki study area varies from lows of $18 \Omega \mathrm{m}$ at VES 8 to highs of $105 \Omega \mathrm{m}$ at VES 16 with an average of $62.94 \Omega \mathrm{m}$. The third layer is the aquiferous zone, the weathered and fractured areasare zones where flow of water is most favorable. Izzi aqiferous zones are found in the third and fourth layer and has values ranging from as low as $30.2 \Omega \mathrm{m}$ at VES 23 to $330 \Omega \mathrm{m}$ at VES 27 with an average of $151.3 \Omega \mathrm{m}$ while the Ishiagu aquiferous zones are found in the third, fourth and fifth layers and have values as low as 10.74 and high as 2338 $\Omega \mathrm{m}$ with an average of $644.67 \Omega \mathrm{m}$.

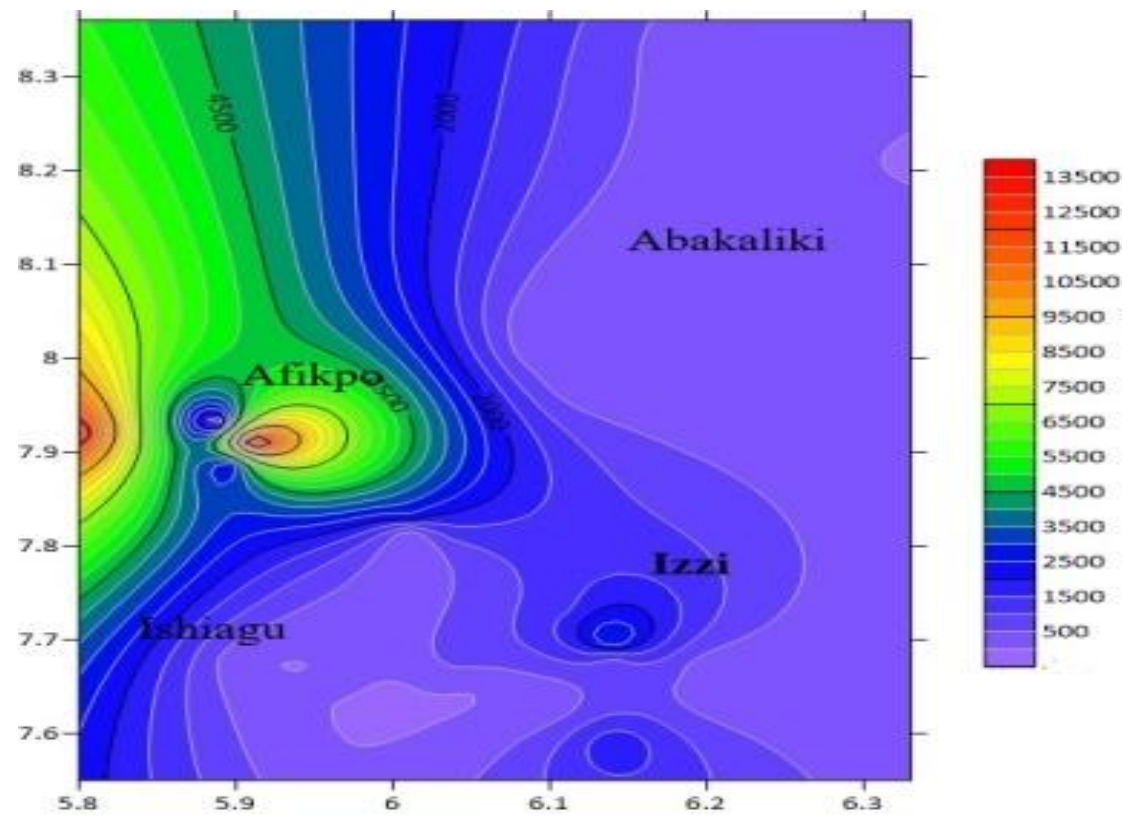

Figure 3: Aquifer resistivity map of the study area

\subsection{Iso-resistivity of the Study Area}

Iso-resistivity maps obtained at depth intervals of $A B / 2=10 \mathrm{~m}$ to $A B / 2=150 \mathrm{~m}$, this showed the resistivity varied vertically with depth. Below are iso-maps derived from resistivity data. After analyzing the maps, it can be observed there is a multi-aquifer system in the study area hydraulically separated by band of clay, shale and sand. 
a.
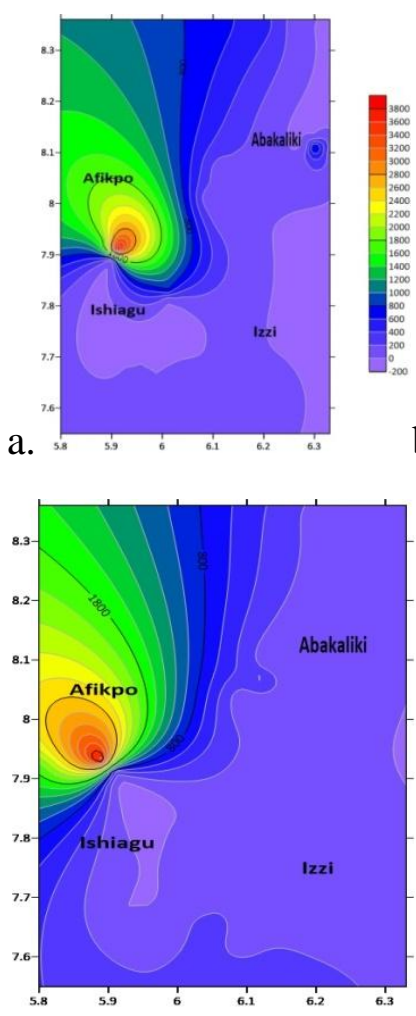

b

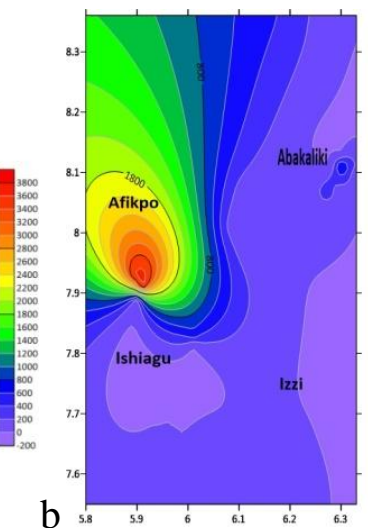

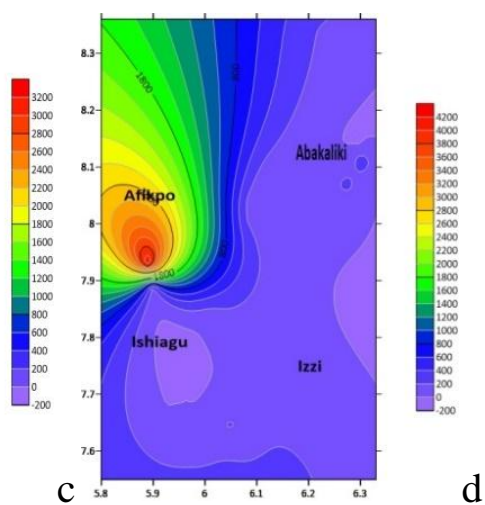

d
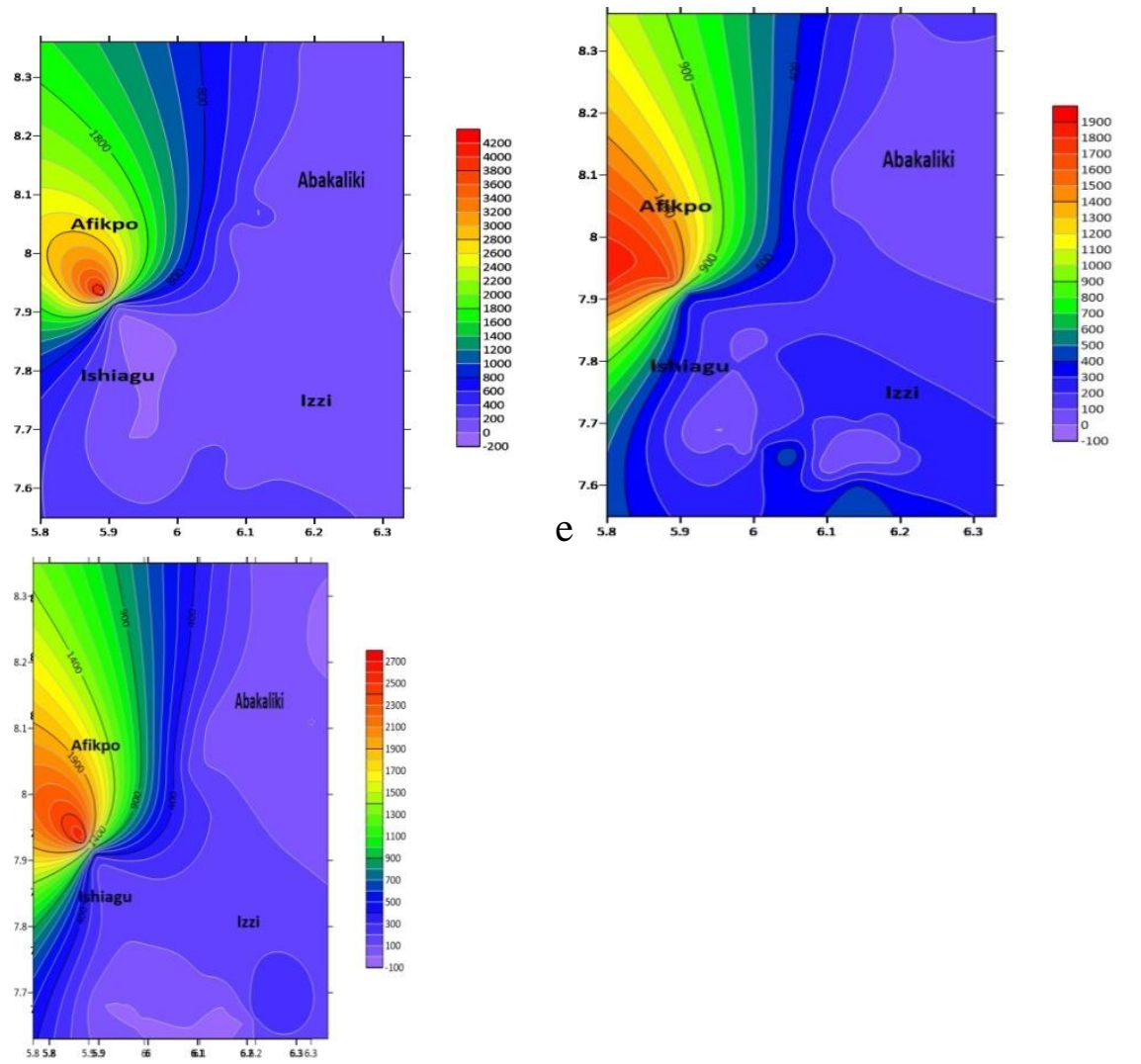

f

Figure 4: Iso-resisitvity maps of the study area: (a) $A B / 2=5$ (b) $A B / 2=10 \mathrm{~m}$ (c) $A B / 2=20 \mathrm{~m}$ (d) $\mathrm{AB} / 2=50 \mathrm{~m}$ (e) $\mathrm{AB} / 2=100$, (f) $\mathrm{AB} / 2=150$

\subsubsection{Isoresistivity $\left({ }^{\mathrm{AB}} / 2=5 \mathrm{~m}\right)$}

The isoresistivity map shown in (figure 4a) revealed most sections asides the western areas are underlain by low resistivity materials. The magenta and deep blue colors indicate areas of low resistivity (figure $4 \mathrm{a}$ ) and have values ranging from $0-1000 \Omega \mathrm{m}$. The Isomodel with a penetration of $10.57 \mathrm{ft}$ showed that the resistance values rose from $200 \mathrm{~m}$ to $38,000 \mathrm{~m}$ (red) throughout the study area. The magenta color shows the area is underlain by clay zone or shales. 


\subsubsection{Isoresistivity Map $\left({ }^{\mathrm{AB}} / 2=10 \mathrm{~m}\right)$}

Iso-map at $10 \mathrm{~m}$ in (Figure 4b) shows that low resistive materials are found in the research area except the region of Afikpo region. Resistivity of the study area was observed in the south, east, central and northern parts of the study area with an appropriate depth of penetration of $13,33 \mathrm{~m}$, with low to medium resistivity varying from 0 to $150 \mathrm{~km}$ (in magenta and bluish). The resistivities have ranges of 450 to $950 \Omega$ mand were found to be restricted to the West of this area, while the medium resistivity values were found for green areas between 150 and $400 \Omega \mathrm{m}$. The crimson and bluish colors is a sign that the area is underlain by shaley or clay units, while other colors are underlain by fractured shale units.

\subsubsection{Isoresistivity Map $\left({ }^{\mathrm{AB}} / 2=20 \mathrm{~m}\right)$}

This iso map shows high resistivity materials such as sandstone to support the Afikpo area. The crimson and bluish colors may in general indicate shale and clay formations, the rest are made up of fractured variations of shale and sandstone.

\subsubsection{Isoresistivity Map $\left({ }^{\mathrm{AB}} / 2=50 \mathrm{~m}\right)$}

Most sections of the study area in the North, East, West and South-Eastern areas are highlighted by relative low resistive materials in the ${ }^{A B} / 2=50 \mathrm{~m}$ iso map in (Figure $4 \mathrm{~d}$ ). The resistivity of the field showed that the shale coverage rose throughout the region as crimson and bluish areas rose. Resistance levels range from 1 and $200 \Omega \mathrm{m}$ in crimson and bluish colored areas. High resistivities between 250 and 700 percent are mostly found within the south-west axis of the study region, with pockets located in its north-west and north-eastern regions. In general, the crimson ad bluish colors of resistivity is an indicator of clay or silt formations while the remaining colors on the map usually represent the areas above fractured shale or shallow and sandstone alternations.

\subsubsection{Isoresistivity Map $\left({ }^{\mathrm{AB}} / 2=100 \mathrm{~m}\right)$}

The iso-map (Figure 4e) below highlights how most parts of the study area are underlain by low resistance materials. The resistivity of the study area revealed that the resistivity values at the sounding points increase from 0 to as high as $1900 \Omega \mathrm{m}$. This depth led to the area becoming shaly as Abakaliki, Izzi and Ishiagu study areas are made of low and medium resistivity materials (magenta color) the range are $0-500 \Omega \mathrm{m}$ while the high resistivity values are found in the western study area.

\subsubsection{Isoresistivity Map $\left({ }^{\mathrm{AB}} / 2=150 \mathrm{~m}\right)$}

The iso-resistivity for $\mathrm{AB} / 2=150 \mathrm{~m}$ (Figure $4 \mathrm{f}$ ) indicated that relatively low resistive materials are used to underlay majority of the study area along the Northern, Eastern and Southwest axes. Penetration depth is given at $100 \mathrm{~m}$ (to $326 \mathrm{ft}$.) the resistivity of the study area showed that the shale units were the across the region with magenta colored areas increasing across the region. Resistivity levels vary from 0 to $700 \Omega \mathrm{m}$ for the magenta colored areas. In general, the west axis is limited to high resistivity values ranging from 700 to $2900 \Omega \mathrm{m}$. 


\subsection{Aquifer Depth}

This was calculated from the Vertical Electrical Sounding data and the map is shown in (Figure 7). The depth to water table in Abakaliki area ranges from $8.11 \mathrm{~m}$ at Ochi Udo city to $89.9 \mathrm{~m}$ at Presco Campus Abakaliki with a mean value of $30.214 \mathrm{~m}$, Afikpo ranges from $6.2 \mathrm{~m}$ at NYSC orientation camp to $24.3 \mathrm{~m}$ at Government college Afikpo with a mean value of $15.63 \mathrm{~m}$, Izzi area ranges from $13.6 \mathrm{~m}$ at Nduna Market square to $45.8 \mathrm{~m}$ at Assembles of God church with a mean value of $21 \mathrm{~m}$ and Ishiagu area ranges from 7.28 at VES 41 to 92.25 at Amalokpa Amonye with a mean value of $31.56 \mathrm{~m}$.

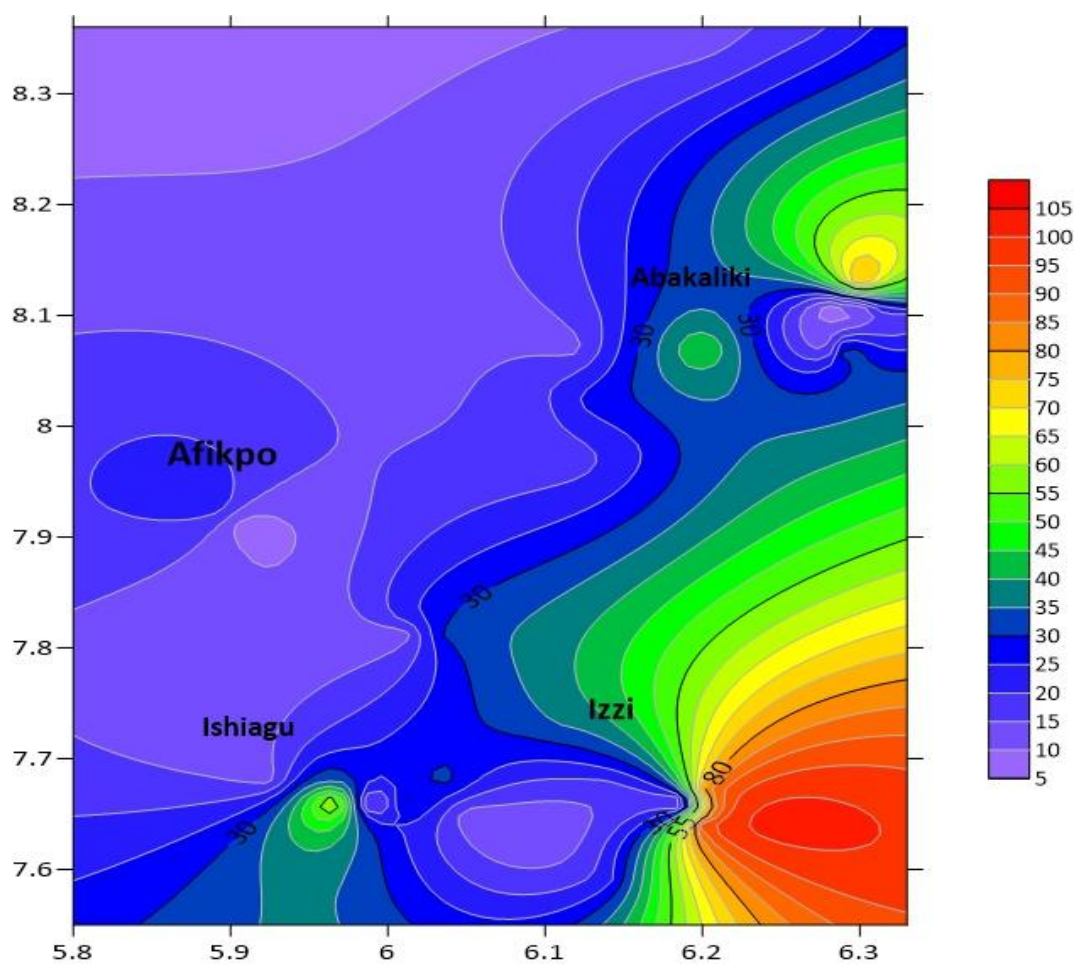

Figure 5: Contour map of aquifer depth of the study area

\subsection{Aquifer Thickness}

Aquifer thickness in Abakaliki ranges from 2.7m in Akam street to 55.2m at Federal Hospital with a mean value of $17.44 \mathrm{~m}$, Afikpo thickness ranges from $2.67 \mathrm{~m}$ at Nysc orientation camp to $16.06 \mathrm{~m}$ at Ukpa by Oko Ogenyi road with an average thickness of $8.77 \mathrm{~m}$, Izzi area aquifer thickness ranges from $2.6 \mathrm{~m}$ to Nkumanyi Mbalukwu to $37.6 \mathrm{~m}$ at Assembles of God Umuogodo with an average value of $13.96 \mathrm{~m}$ and Ishiagu area thickness ranges from $55.87 \mathrm{~m}$ at Ekengwu Amaonyi to $2.33 \mathrm{~m}$ at Federal college of agriculture with an average of $18.67 \mathrm{~m}$. The aquifer thickness map is shown in figure 6. 


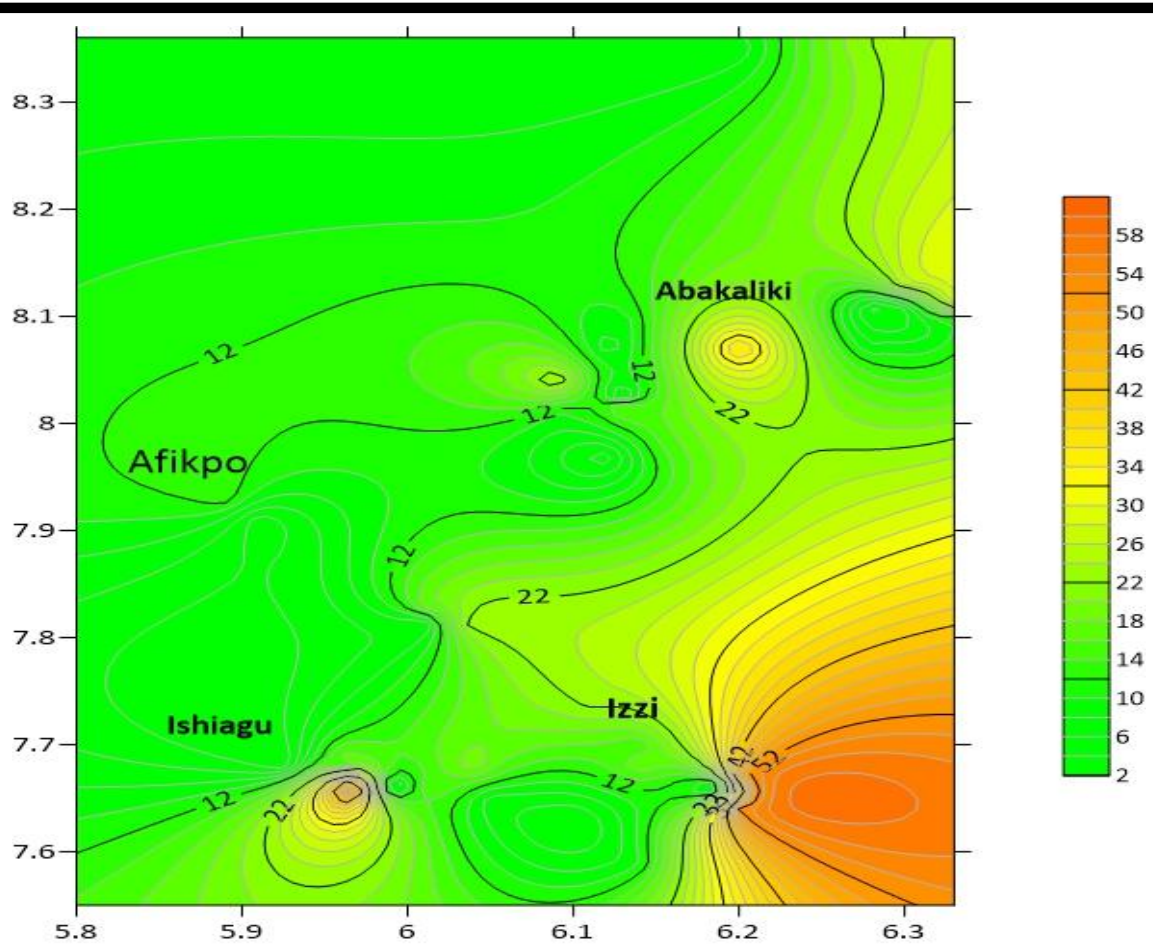

Figure 6: Aquifer thickness maps of the study area

\subsection{Dar-Zarrouk Parameters of the Study Area}

\subsubsection{Transverse Resistance}

The parameter known as the Dar-zarrouk Parameter has also been measured (Table 1). Transverse resistance is the product of aquifer resistivity and aquifer thickness. This is estimated as low as $3999.54 \Omega \mathrm{m}^{2}$ in Afikpo region and as high as $388964.52 \Omega \mathrm{m}^{2}$ and an average of $31503.10 \Omega \mathrm{m}^{2}$. Abakaliki area varies from 65.34 per $\Omega \mathrm{m}^{2}$ up to $2073.99 \Omega \mathrm{m}^{2}$ on average from $1000.50 \Omega \mathrm{m}^{2}$; the Izzi area is as low as 78.52 $\Omega \mathrm{m}^{2}$ and as high as $7079.12 \Omega \mathrm{m}^{2}$ with an average of $1983 \Omega \mathrm{m}^{2}$ and Ishiagu varies from $26.28 \Omega \mathrm{m}^{2}$ to $40587.68 \Omega \mathrm{m}^{2}$ with average values of $10852 \Omega \mathrm{m}^{2}$. The Afikpo study area has the highest transverse resistance (Figure 7) and is believed to have high transmissibility and aquifer unit output (Agbasi and Edet, 2016). 
International Journal of Advanced Academic Research | ISSN: 2488-9849

Vol. 7, Issue 4 (April, 2021) | www.ijaar.org

Journal DOI: www.doi.org/10.46654/ij.24889849

Article DOI: www.doi.org/10.46654/ij.24889849.e7437

Table 1: Aquifer properties from resistivity data

\begin{tabular}{|c|c|c|c|c|c|c|c|}
\hline $\mathrm{S} / \mathbf{N}$ & LOCATION & $\begin{array}{r}\text { Aquifer } \\
\text { Resistivity } \\
(\text { ohm-m) pa }\end{array}$ & $\begin{array}{r}\text { Aquifer } \\
\text { Depth (m) }\end{array}$ & $\begin{array}{r}\text { Aquifer } \\
\text { Thickness } \\
(\mathbf{m})\end{array}$ & $\begin{array}{r}\text { Aquifer } \\
\text { Conductivity } \\
\sigma=1 / \rho_{\mathrm{a}}\end{array}$ & $\begin{array}{l}\text { Transverse } \\
\text { Resistance } \\
R=\left(\begin{array}{l}\rho \\
\text { x l I }\end{array}\right)\end{array}$ & $\begin{array}{r}\text { Longitudinal } \\
\text { Conductance } \\
\mathrm{S}=\text { Thickness } / \text { pa }\end{array}$ \\
\hline 1 & Akani Ibiam Federal Polytechnic Uwana & 13203.00 & 19.2 & 10.67 & $7.57404 \mathrm{E}-05$ & 140876.01 & 0.00080815 \\
\hline 2 & NNPC FILLING STATION AM ASIRI & 2638 & 11.4 & 4.05 & 0.000379075 & 10683.9 & 0.001535254 \\
\hline 3 & GOVERNMENT COLLEGE AFIKPO & 556.00 & 24.3 & 13.4 & 0.001798561 & 7450.4 & 0.024100719 \\
\hline 4 & NYSC ORIENTATION CAMP AFIKPO & 14556.00 & 6.2 & 2.67 & $6.87002 \mathrm{E}-05$ & 38864.52 & 0.00018343 \\
\hline 5 & UKPA BY OKO OGENYI ROAD AFIKPO & 1155.00 & 23.6 & 16.06 & 0.000865801 & 18549.3 & 0.013904762 \\
\hline 6 & FEDERAL HOSPITAL ABAKALIKI & 74.13 & 32.03 & 26.82 & 0.013489815 & 1988.1666 & 0.361796843 \\
\hline 7 & ABAKALIKI LOCAL GOVERNMENT & 80.70 & 34.7 & 9.5 & 0.012391574 & 766.65 & 0.11771995 \\
\hline 8 & OCHI UDO CITY ABAKALIKI & 18 & 8.11 & 3.63 & 0.055555556 & 65.34 & 0.201666667 \\
\hline 9 & INTERNATIONAL M ARKET ABAKALIKI & 80.7 & 79.40 & 25.7 & 0.012391574 & 2073.99 & 0.318463445 \\
\hline 10 & EZI NWACHI NDIBE, AFIKPO NORTH & 382 & 16.50 & 10.47 & 0.002617801 & 3999.54 & 0.027408377 \\
\hline 11 & EZI-EGWU UBANA UGWU-EGU, AFIKPO NORTH & 24.1 & 8.23 & 4.07 & 0.041493776 & 98.087 & 0.168879668 \\
\hline 12 & PRESCO CAMPUS EBSU ABAKALIKI & 50 & 89.9 & 55.2 & 0.02 & 2760 & 1.104 \\
\hline 13 & ABOFFA VILLAGE SQUARE ABAKALIKI & 45 & 12 & 7.5 & 0.022222222 & 337.5 & 0.166666667 \\
\hline 14 & OROKEOUHA ABAKALIKI & 28 & 13 & 8.5 & 0.035714286 & 238 & 0.303571429 \\
\hline 15 & NKALIKI EBONYI STATE HOUSE OF ASSEMBLY & 85 & 12 & 6 & 0.011764706 & 510 & 0.070588235 \\
\hline 16 & AKAM STREET ABAKALIKI & 105 & 4.5 & 2.7 & 0.00952381 & 283.5 & 0.025714286 \\
\hline 17 & NWANU VILLAGE SQUARE, IZZI & 86.7 & 12 & 6.5 & 0.011534025 & 563.55 & 0.074971165 \\
\hline 18 & ASSEMBLES OF GOD UMUOGODO OSHA OHAUKWU & 102.0 & 45.8 & 37.6 & 0.009803922 & 3835.2 & 0.368627451 \\
\hline 19 & EDUKWU ACHI, AGBAJA, IZZI & 104.7 & 18.2 & 8.8 & 0.009551098 & 921.36 & 0.084049666 \\
\hline 20 & AM AECHARA VILLAGE SQAURE, IZZI & 86.3 & 18.2 & 25.1 & 0.011587486 & 2166.13 & 0.290845886 \\
\hline 21 & NDIAKPARA PRIM ARY SCHOOL, NWAEZENYI, IZZI & 124.8 & 26.5 & 17.4 & 0.008012821 & 2171.52 & 0.139423077 \\
\hline 22 & OFIA NKWU NWAEZENYI, IZZI & 574.7 & 27.8 & 4.3 & 0.001740038 & 2471.21 & 0.007482165 \\
\hline 23 & NKWUM ANYI MBALUKWU IZZI & 30.2 & 17.8 & 2.6 & 0.033112583 & 78.52 & 0.086092715 \\
\hline 24 & OKWARAKA, EZZA-INYIM AGU, IZZI & 132.0 & 22.3 & 13.3 & 0.007575758 & 1755.6 & 0.100757576 \\
\hline 25 & NDUNA M ARKET SQAURE, AGBAJA IZZI & 41.5 & 13.6 & 6.7 & 0.024096386 & 278.05 & 0.161445783 \\
\hline 26 & ALIBARU VILLAGE SQUARE AGBOJA IZZI, & 50.6 & 17.2 & 9.9 & 0.019762846 & 500.94 & 0.195652174 \\
\hline 27 & NWOMILLA VILLAGE SQUARE, MGBAUKWU IZZI & 330.8 & 15 & 21.4 & 0.003022975 & 7079.12 & 0.064691657 \\
\hline 28 & Civic Centre Amaeze & 82.33 & 35.71 & 20.37 & 0.012146241 & 1677.0621 & 0.247418924 \\
\hline 29 & Onovo Ukwu Amaeze & 1957 & 23.09 & 9.7 & 0.000510986 & 18982.9 & 0.004956566 \\
\hline 30 & Imuhuebe Amaeze & 3240 & 29.32 & 14.21 & 0.000308642 & 46040.4 & 0.004385802 \\
\hline 31 & AGM Primary School & 737.2 & 31.04 & 19.27 & 0.001356484 & 14205.844 & 0.026139447 \\
\hline 32 & Assemblies of God Church & 1337 & 36.18 & 22.25 & 0.000747943 & 29748.25 & 0.016641735 \\
\hline 33 & Ekengwu Amaonye & 90.63 & 65.55 & 55.87 & 0.011033874 & 5063.4981 & 0.61646254 \\
\hline 34 & GMSS Ihietutu Ishiagu & 33.13 & 31.92 & 15.73 & 0.030184123 & 521.1349 & 0.474796257 \\
\hline 35 & Amabor Amaonye Ishiagu & 79.65 & 81.15 & 49.75 & 0.012554928 & 3962.5875 & 0.624607659 \\
\hline 36 & Amalokpa Amonye Ishiagu & 137.6 & 92.25 & 51.94 & 0.007267442 & 7146.944 & 0.37747093 \\
\hline 37 & Near Echiele Development Center, Amokwe Ishiagu & 41.13 & 12.1 & 5.28 & 0.024313153 & 217.1664 & 0.12837345 \\
\hline 38 & General Hospital Amaokwe Ishiagu & 1242 & 31.62 & 23.12 & 0.000805153 & 28715.04 & 0.018615137 \\
\hline 39 & Near Christ Embassy , Amaokwe Ishiagu & 2338 & 23.25 & 17.36 & 0.000427716 & 40587.68 & 0.00742515 \\
\hline 40 & Ngwogwo Primary School, Ngwogwo Ishiagu & 17.87 & 12.31 & 6.92 & 0.055959709 & 123.6604 & 0.387241186 \\
\hline 41 & HighnigHonfen Primary School, Amaokwe Ishiagu & 14.85 & 7.28 & 3.61 & 0.067340067 & 53.6085 & 0.243097643 \\
\hline 42 & Aguena Primary School, Okue Ishiagu & 431.7 & 10.61 & 3.74 & 0.002316423 & 1614.558 & 0.008663424 \\
\hline 43 & Federal College of Agriculture Ishiagu & 11.28 & 13.14 & 2.33 & 0.088652482 & 26.2824 & 0.206560284 \\
\hline 44 & Ivo Divisional Police Headquarters ,Ishiagu & 873.8 & 19.8 & 18.2 & 0.001144427 & 15903.16 & 0.020828565 \\
\hline 45 & 1shiagu high school, Ishiagu & 48.11 & 11.09 & 3.84 & 0.020785699 & 184.7424 & 0.079817086 \\
\hline 46 & Obioha Primary School, Amagu Ishiagu & 10.74 & 30.92 & 17.74 & 0.09310987 & 190.5276 & 1.651769088 \\
\hline 47 & sir G.C. Ajah residence, Amagu Ishiagu & 169.5 & 32.87 & 12.3 & 0.005899705 & 2084.85 & 0.072566372 \\
\hline
\end{tabular}




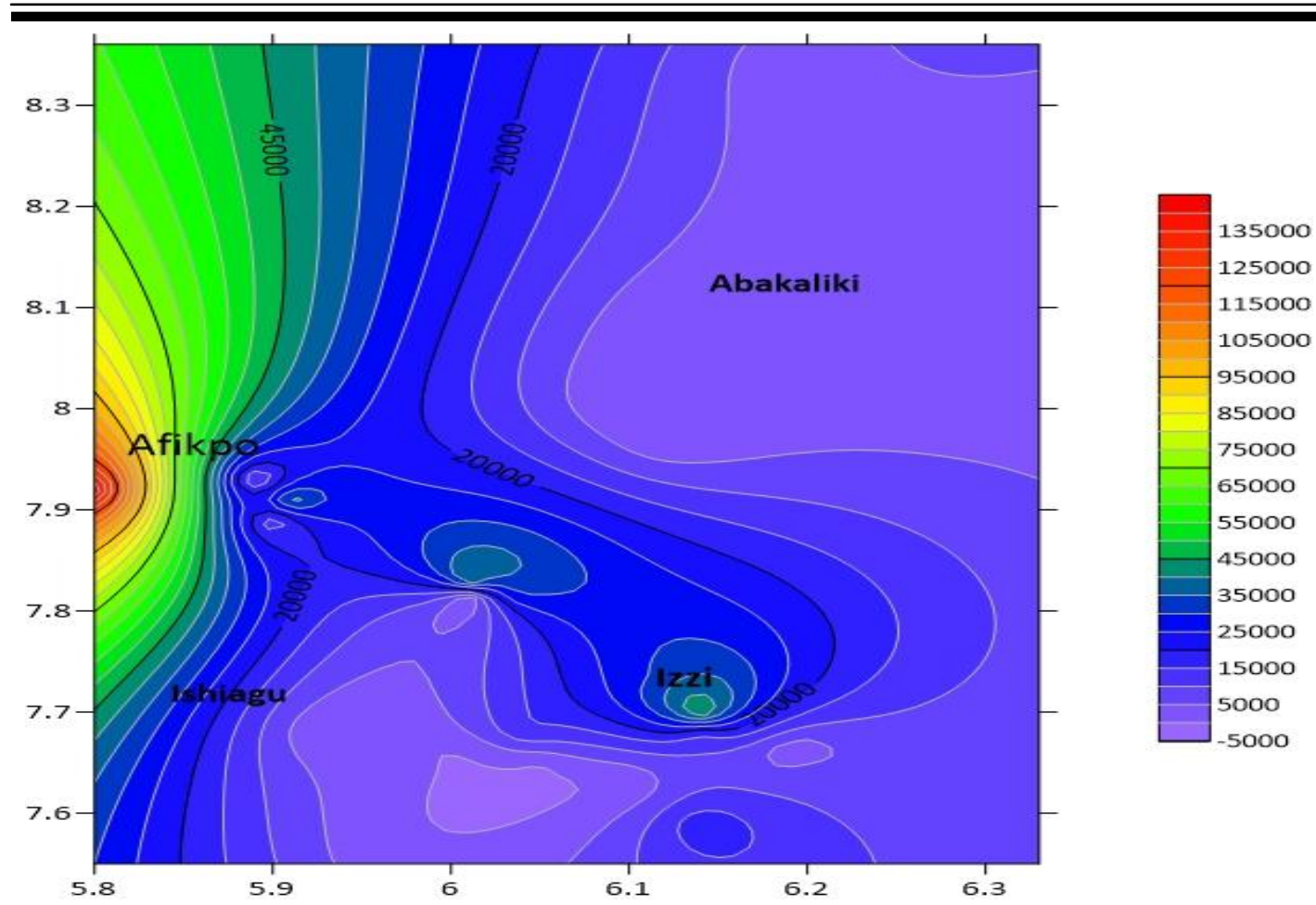

Figure 7. Spatial variation of transverse resistance $\left(\Omega \mathrm{m}^{2}\right)$ across the study area

\subsubsection{Longitudinal conductance}

The dissemination of aquifer longitudinal conductance $(S)$ is shown in Table 5. Afikpo values range from 0.0018343 to 0.027 with an average of 0.033 , Abakaliki varies from 0.0257 to 1.104 with an average of 0.29 , and Izzi has values from 0.0074 to 0.36862 with an average of 0.143 while Ishiagu varies from 0.0043 to 1.65 with an average of 0.260 . In the assessment of aquifer protective capacity, longitudinal conductance values are usually used. The aquifer protective capacity basically measures the natural ability of overburden layers to filter or slow percolating pollutants [Olorunfemi et al, 1999]. The longitudinal conductance values of the study area have been categorized to low, medium, moderate and strong aquifer protection capacity as shown in Table 2 (Oladapo and Akintorinwo, 2007).

Table 2: Aquifer protective capacity rating of the study area using Longitude Conductance (Oladapo and Akintorinwo, 2007).

\begin{tabular}{|c|l|}
\hline $\begin{array}{l}\text { Longitudinal conductance } \\
\text { (mhos) }\end{array}$ & Protective capacity rating \\
\hline$>10$ & Excellent \\
\hline 10 & Very Good \\
\hline $0.7-4.9$ & Good \\
\hline $0.2-0.69$ & Moderate \\
\hline $0.1-0.19$ & Weak \\
\hline$<0.1$ & Poor \\
\hline
\end{tabular}




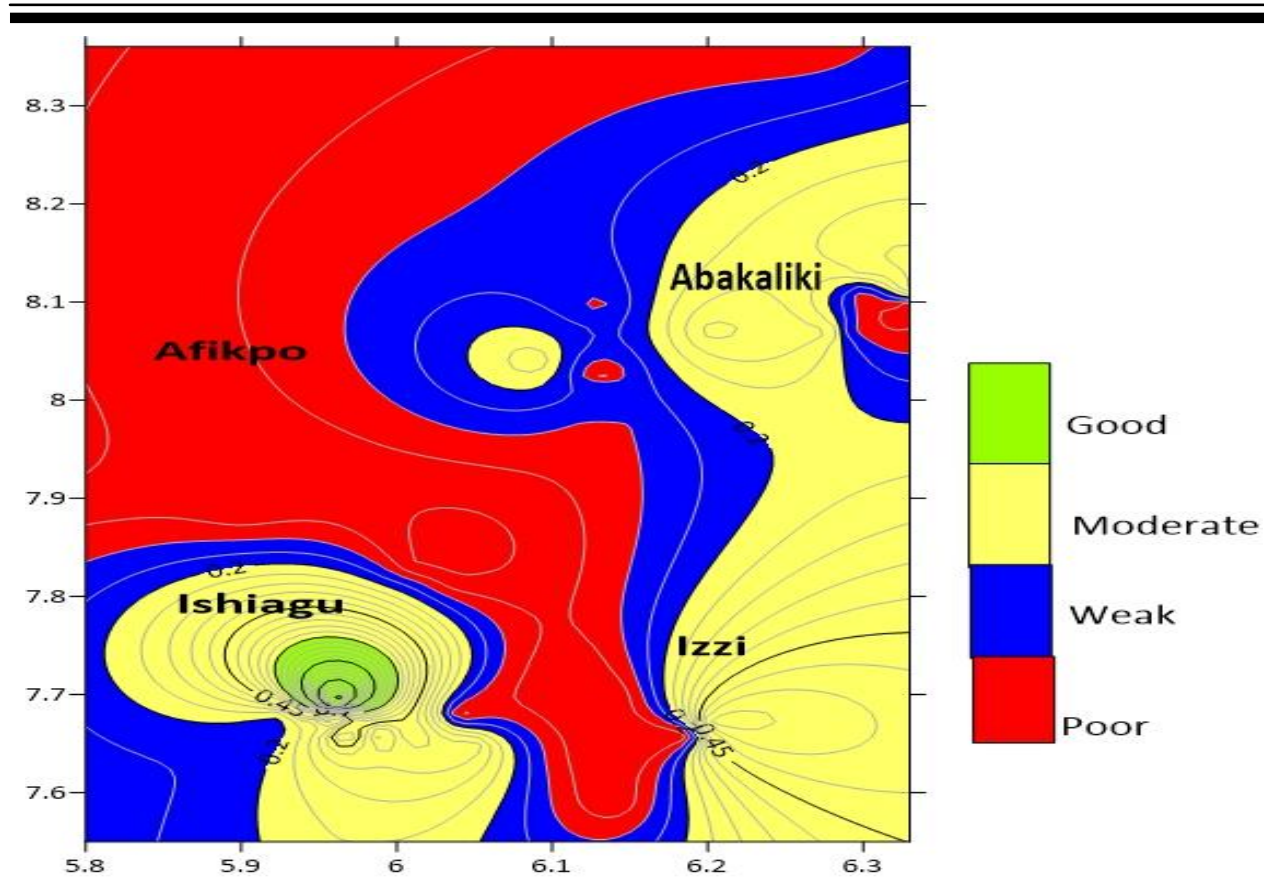

Figure 8: Aquifer protective capacity map of the study area

In comparison with other regions, the Afikpo region of the study shows a relatively lower aquifer protective capacity, since it consists of sands which are alternating, rendering it vulnerable to pollution due to the high permeability of sand compared to Abakaliki and Ishiagu which is dominated by shale, except when fractured or weathered. Eyankware et al. (2020) carried out an estimation on aquifers in Abakaliki and discovered their study area was underlain by clay/shale and fractured shale and most parts are underlain by materials of poor to excellent protective capacity.

\subsection{Summary, Conclusion and Recommendation}

The hydro-geophysical study of the study area using surficial resistivity data have been carried out with the objective of appraising the groundwater potentials of the area.

Results of the study revealed that the geoelectric curves interpreted from the study area are QH, QQ, HHK, etc. with the dominant curve type being the HKHK type. The aquifer resistivity varies from $10.74 \Omega \mathrm{m}$ at VES 46 to $13201 \Omega \mathrm{m}$ at VES1 with an average of 1013.58 $\Omega \mathrm{m}$, Aquifer depth ranges from $6.2 \mathrm{~m}$ at VES 4 to $92.5 \mathrm{~m}$ at VES 36 with an average aquifer depth of $27.07 \mathrm{~m}$, The layer resistivity varies across the study area thus reflecting the geological complexity area of study with the aquifer resistivity values across the area varying from as low as $18 \Omega \mathrm{m}$ to as high as $14,556 \Omega \mathrm{m}$. Transverse resistance varies from $65.34 \Omega \mathrm{m}^{2}$ at VES 10 to $7079.14 \Omega \mathrm{m}^{2}$ at VES 29 with an average of $9966.29 \Omega \mathrm{m}^{2}$ and the longitudinal conductance varies from $0.00018 \Omega^{-1}$ at VES 6 to $1.65 \Omega^{-1}$ at VES 46 with an average of $0.026 \Omega^{-1}$.

The findings of this study revealed that the aquifer potentials of the study areas were revealed to be variable with the aquifer type, nature and characteristics generally controlled by the underlying geology. The areas with the highest transverse resistance values are expected to give the highest groundwater yield. Areas for future groundwater development have been suggested on the ground of high transverse resistance values. It was there concluded that the 
southern study area has a high aquifer potential when compared to the northern part. The Longitudinal conductance revealed the Afikpo area has low aquifer protection compared to the other areas that offer weak to moderate aquifer protection

In addition, the Eze Aku formation was delineated as the formation with the greatest aquifer potentials in the study area. It is therefore recommended that a detailed groundwater exploration should be carried out before siting a borehole in the study area.

\subsection{Acknowledgments}

The support of the management and staff of the Federal University of Technology, Owerri is also highly appreciated. 


\subsection{References}

Adelana,S.M.A., Olasehinde, P.I., Bale, R.B., Vrbka, P., (2008). An overview of Geology and Hydrogeology of Nigeria. In: Adelana,S.M.A and MacDonald, A.M (Eds.), Applied Groundwater Studies in Africa. Iah Selected Papers on Hydrogeology, CRC Press/Balkema, London, UK (13): pp171-197.

Akaolisa, C.C.Z., (2006). Aquifer transmissivity and basement structure determination using resistivity sounding at Jos, Plateau state, Nigeria. Environ. Monit. Assess. 114:27-34.

Arabi S.A., Dewu, B.B.M.,, Muhammad A.M., Ibrahim, M.B., Abafoni, J.D., (2008). Determination of weathered and fractured zones in part of the basement complex of North-Eastern Nigeria.J. Eng. Technol.Res. 2(11):213-218.

Ayers J.F., (1989). Conjunctive use of geophysical and geological methods in the study of alluvial aquifer. Ground Water 27:625-632.

Benkhelil, J., Daindli, P., Ponsard, J. F., Popoff, M. \& Saugy, L., (1988). The Benue Trough: wrench fault related basins on the border of the Equatorial Atlantic. In: Manspeizer, W. (ed.) Triassic Jurassic Rifting. Developments in Gcottc tonics, 11. Amsterdam: Elsevier, pp. $787-816$.

Eke. D.R., Opara. A.I., Inyang. Emberga,T.T.,Echetama,H.N.,Ugwuegbu,C.A.,Onwe,R.M. Onyema, J.C., \&Chinaka, J.C., (2015).Hydrogeophysical evaluation and vulnerability assessment of shallow aquifers of the Upper Imo River Basin, Southeastern Nigeria. Am. J. Environ. Protect., 3 (4), pp. 125-136

El-Hussaini AH, Ibrahim HA, Bakhelt AA (1995). Interpretation of geoelectrical data from an area of the entrance of Wadi Qena, eastern Desert, Egypt. J. King Saudi Univ. $7: 257-276$.

Ekwe, A.C.,\&Opara, A.I. (2012). Aquifer transmissivity from surface geoelectrical data: a case study of Owerri andEnvirons, Southeastern Nigeria. Journal of Geological Society India: 355-378.

Ekwe, A. C., Opara, A. I., Okeugo, C. G., (2020). Determination of aquifer parameters from geosounding data inparts of Afikpo Sub-basin, Southeastern Nigeria. Arabian Journal of Geosciences, 13, 189.https://doi.org/10.1007//s12517-020-5137-y.

Emberga, T. T., Opara, A. I., Onyekuru, S.O., Omenikolo, A. I., Nkpuma, O.R., \&Eluwa Nchedo, E. N. (2019).Regional hydrogeophysical study of the groundwater potentials of the Imo River Basin Southeastern Nigeria using surficial resistivity data.Australian Journal of Basic and Applied Sciences, 13(8), 76-94.https://doi.org/10.22587 /ajbas .2019.13.8.12.

Ejiogu, B.C., Opara, A.I., Nwosu, E.I., Nwofor, O.K., Onyema, J.C \& Chinaka, J.C. (2019). Estimates of aquifer geohydraulicand vulnerability characteristics of Imo State and environs, Southeastern Nigeria, using electricalconductivity data. Environmental Monitoring and Assessment, 191, 1-19. https//doi 10.1007/s10661-019-7335-1. 
Eyankware, M.O., Ogwah, C., \&Selemo, A.O.I., (2020). Geoelectrical parameters for the estimation of groundwaterpotential in fracture aquifer at sub-urban area of Abakaliki, SE Nigeria. International Journal of Earth Scienceand Geophysics, 6, 031.

Ezeh Hilary N., Anike,O.L.,(2009). The preliminary assessment of the pollution status of streams and artificial lakes created by mining in the mining district of Enyigba, South Eastern Nigeria, and their consequences.

Igbokwe, M.U., Okwueze, E.E.,\&Okereke, C.S., (2006). Delineation of Aquifer zones from Geoelectric Sounding inKwa Ibo River Watershed, South Eastern Journal of Engineering and Applied science, 1(4), 410-421.

Inyang, G, E., Opara, A.I., Ubechu, B.O., Nwachukwu, H. G., Eluwa, N., Amadi, C. C., Emberga, T.T., \& Eke, D.R.,(2017).Geophysical Appraisal of the Aquifer Geomaterials of Ugep and Environs,Southeastern, NigeriaUsing Resistivity Data.Journal of Geography, Environment and Earth Science International, 9(2), 1-24; DOI:10.9734/JGEESI/2017/30349.

Joshua, E.O., Odeyemi,O.O., \&Fawehinmi, O.O., (2011).Geoelectric investigation of groundwater potential of the Moniya Area, Ibadan.Journal of Geol.Min.Res, 3,54-62.

Keller, G.V.,\&Frischnechk, F.C., (1979). Electrical methods in geophysical prospecting. Pergamon Press, New York, pp.91 - 135.

Murat, R.C., (1970). Stratigraphy and Palaeogeography of the Cretaceous and Lower Tertiary in Southern Nigeria". In: Dessauvagie, F.J and Whiteman, A.J. (ed). African Geology.University of Ibadan Press: Ibadan, Nigeria. pp 251-266.

Ngwoke, M.O., (2013). Determination of Aquifer Parameters in Ishiagu Ebonyi State using Geoelectric Method. Unpublished M.Sc Thesis, University of Nigeria, Nsukka

Niwas S, Singhal D.C., (1981).Estimation of aquifer transmissivity from Dar Zarrouk Parameters in porous media. J Hydrol 24:344-353

Nwankwoala, H.O., (2015). Hydrogeology and Groundwater Resources of Nigeria, New York Science Journal 8(1): pp.89-100.

Obiora,D.N.,Ibuot,J.C., \&George,N.J., (2015).Evaluation of aquifer potential, geoelectric and hydraulic parameters in Ezza North, southeastern Nigeria, using geoelectric soundingInt. J. Environ. Sci. Technol.

Ofoegbu, C.O.,(1985). “A review of the Geology of the Benue trough of Nigeria”. J. Afri. Earth Sci. vol. 3, pp $283-291$.

Oladapo, M.I,,Akintorinwa, O.J., (2007). Hydrogeophysical study of Ogbese, Southwestern, Nigeria. Glob J Pure Appl Sci 13: 55-61.

Oni, T.E, Omosuyi, G.O, Akinlalu, A.A., (2017). Groundwater vulnerability assessment using hydrogeologic and geoelectric layer susceptibility indexing at Igbara Oke, Southwestern Nigeria. NRIAG Journal of Astronomy and Geophysics 6: 452-458. 
Onuoha, K.M.,\& Mbazi, F.C.C., (1988).Aquifer Transmissivity from Electrical Sounding Data. The Case of Ajali Sandstone Aquifers, South-West of Enugu. In: Ofoegbu, C.O(Ed), Ground Water and Mineral Resources ofNigeria, Fried-vieweg and Sohn, Wiesbaden, 17-29.

Opara, A. I., Onu, N.N., \&Okereafor, D.U., (2012). Geophysical Sounding for the Determination of Aquifer Hydraulic Characteristic from Dar-Zarrock parameters: Case Study of Ngor-Okpala, Imo River Basin Southeastern Nigeria. The Pacific Journal of Science and Technology, 13(1), 590-603.

Reyment R.A., (1965). Aspects of Geology of Nigeria. Ibadan university press; 145.

Reyment, R. A., (1967). Aspects of the Geology of Nigeria. The Stratigraphy of the Cretaceous and Cenozoic Deposits. Ibadan University Press. P. 1-181.

Snyder J.D., Merson M.H., (1982). The Magnitude of the Global Problem of Acute Diarrhoeal Disease: A Review of Acute Surveillance Data. Bull. World Meteorol. Organ. 60:605-613.

Tijani M.N., Loehnert EP, Uma KO (1996). Origin of saline groundwaters in the Ogoja area, Lower Benue Basin, Nigeria. J. Afr. Earth Sci., 23(2): 237-252.

Tizro A.T., Voudouris K.S., Salchzade M, Mashayekhi H., (2010). Hydrogeological framework and estimation of aquifer hydraulic parameter using geoelectrical data: a case study from West Iran. Hydrogeol. J. 18:917-929.

Ugada, U., (2012). Hydrogeophysical evaluation of aquifer hydraulic characteristics using surface geophysical data: a case study of Umuahia and Environs, Southeastern Nigeria, M.ScThesis. Federal University of Technology, Owerri, p 250.

Ugada, U., Opara, A.I., Emberga, T.T., Ibim, D.F., Omenikoro, A.I \& Womuru, E.N. (2013). Delineation of ShallowAquifers of Umuahia and Environs, Imo River Basin, Nigeria, Using Geo-Sounding Data. Journal of WaterResource and Protection, 5. 1097-1109.

Ugada, U., Ibe, K.K., Akaolisa, C.Z \&Opara, A.I. (2014). Hydrogeophysical evaluation of aquifer hydrauliccharacteristics using surface geophysical data: a case Study of Umuahia and environs, Southeastern Nigeria;Arabian Journal of Geosciences. DOI: $10.1007 / \mathrm{s} 12517-013-1150-8$.

Uma, K.O., (1989). An appraisal of the groundwater resources of the Imo River Basin. Nigerian Journal of Mining and Geology, vol.25, nos. 1 and 2, pp. 305 - 315.

Ward, S.H. (1990). Resistivity and Induced Polarization Methods in Geotechnical and Environmental Geophysics. Society of Exploration Geophysicists, Tulsa, 147-189.

Zohdy AAR, Eaton GP, Mabey DR (1974). Application of surface geophysics to groundwater investigation. Techniques of Water Resources Investigation, U.S. Geological Survey. p.116. 
International Journal of Advanced Academic Research | ISSN: 2488-9849

Vol. 7, Issue 4 (April, 2021) | www.ijaar.org

Journal DOI: www.doi.org/10.46654/ij.24889849

Article DOI: www.doi.org/10.46654/ij.24889849.e7437

Zohdy, A.A.R., (1976). Application of surface geophysics (Electrical methods to groundwater investigations) in: Techniques for water resources investigations in the United States Section D, book 2, pp. 5 - 55. 
International Journal of Advanced Academic Research | ISSN: 2488-9849

Vol. 7, Issue 4 (April, 2021) | www.ijaar.org

Journal DOI: www.doi.org/10.46654/ij.24889849

Article DOI: www.doi.org/10.46654/ij.24889849.e7437

\section{DECLARATIONS}

\section{Data availability}

The datasets generated during and/or analysed during the current study are available from the corresponding author on reasonable request.

Funding: This research was funded by the corresponding author.

Conflicts of interest/Competing interests: There are no conflicts of interest. 